\title{
SME Knowledge Commercialization Through Public Sector Partnerships
}

\author{
Neil A. Thompson \\ Department of Management and Organization \\ VU University Amsterdam, de Boelelaan 1105 \\ 1081 HV Amsterdam, The Netherlands \\ n.a.thompson@vu.nl \\ Andrea M. Herrmann \\ Department of Innovation, Environmental and Energy Studies \\ Utrecht University \\ Domplein 29, 3512 JE Utrecht, The Netherlands \\ Marko P. Hekkert \\ Department of Innovation \\ Environmental and Energy Sciences \\ Utrecht University \\ Domplein 29, 3512 JE Utrecht, The Netherlands
}

Received 1 March 2016

Accepted 1 March 2017

Published 19 March 2018

\begin{abstract}
Collaborating with public research organizations (PROs) helps SMEs acquire the knowledge and skills they need to successfully innovate. But do they also help SMEs reduce their exposure to involuntary knowledge misappropriation and legitimacy deficits? Building from transaction economics and population ecology theories, we hypothesize that innovative SMEs collaborate with PROs to not only co-develop knowledge, but also to mitigate the risk that knowledge will be misappropriated from larger firms as well as to build overall organizational legitimacy. Binary and ordinal regression analyses using the EIM Technology Panel including 779 innovative SMEs in the Netherlands reveal that some of the variations in SME innovation partnership behavior may indeed be explained by efforts to avoid knowledge misappropriation and gain endorsements and affiliation with highly legitimate PROs.
\end{abstract}

Keywords: Knowledge misappropriation; organizational legitimacy; innovation barriers; SME partnerships.

\section{Introduction}

It is hard to understate innovation's importance for firm competitiveness, productivity, and growth. Yet, successful innovation remains elusive for many firms, especially for SMEs. To increase innovative output, scholars using the knowledgebased view (KBV) of the firm argue that SMEs engage in open innovation 
partnerships with, among others, public research organizations (PROs) because this allows them to complement their internal absorptive capacity [Fabrizio (2009)] and develop crucial know-how [Chiang and Hung (2010); Mohnen and Hoareau (2003)]. Accordingly, a number of empirical studies have shown that cooperative R\&D projects with PROs are essential to keep pace with technological change and to develop new products [Fontana et al. (2006); Zeng et al. (2010)].

In this paper, we test hypotheses and find evidence for two additional explanations for SME open innovation partnerships with PROs — reducing the risk of knowledge misappropriation and legitimacy deficits. First, open innovation has long been recognized as a double-edged sword [Teece (1986)]: inter-firm collaboration often also leads to transaction costs and involuntary knowledge misappropriation [Mukherjee et al. (2013)]. While entering into partnerships may facilitate positive knowledge spillover from larger organizations to SMEs, it also opens the door for opportunistic behaviors by larger collaborators to obtain knowledge outside of existing contracts [Parkhe (1993); Sawers et al. (2008)]. Biotechnology, for instance, is an industry that has been identified with the highest frequency of collaborations among several industries characterized by high alliance activity [Hagedoorn (1993)], a context with extremely high uncertainty [Hill and Rothaermel (2003)] and high rates of involuntary knowledge misappropriation [Herrmann (2008)]. Building from transaction cost economics (TCE), we hypothesize that biotechnology SMEs will choose open innovation partners with PROs based also on the alignment of incentives and goals [Inkpen and Tsang (2005)]. In other words, collaborating universities and research institutes may offer a solution to the knowledge misappropriation problem because PROs not only provide needed capabilities, but also have a low risk of misappropriating co-produced knowledge used for new product development [Kale et al. (2000)].

Second, knowledge-based theorists argue that innovative SMEs openly collaborating with PROs do so by taking specific actions, such as joint R\&D projects, sharing facilities and resources, or outsourcing research, under the joint aim of knowledge co-production [Fontana et al. (2006)]. Nevertheless, SMEs undertake a number of actions that do not seem closely related to new product development. Drawing on population ecology theory of organizations [Hannan and Freeman (1977); Zucker (1989)], we suggest that innovative SMEs, who operate in immature industries, will more often undertake non-product development activities, such as seeking endorsements and affiliations, in an effort to reduce their exposure to legitimacy deficits. Population ecology scholars argue that the routines, products, and technologies of innovative SMEs in immature industries are less institutionalized [Meyer and Rowan (1977)] — also known as the liability of newness [Freeman et al. (1983)] — and therefore need to generate cultural support necessary for resource acquisition [Hannan and Carroll (1992)] to increase the odds of successful innovation [Bridwell-Mitchell and Mezias (2012); Hall et al. (2011); Low and Johnston (2010)]. The emerging clean technology has been found to be particularly exposed to legitimacy issues due to the benefits of direct use not fully captured by the consumer but by society-at-large [Rennings (2000)]. Consumer selection of cleantech products therefore are not purely driven by rational economic motives but also by normative, 
institutional factors. Thus, we hypothesize that innovative cleantech SMEs are likely to not only engage in joint R\&D projects with PROs, but also build affiliations and seek endorsements to reduce risks of legitimacy deficits.

Using the "technology ventures panel" of the EIM Policy and Research Institute, a comprehensive database on innovation partnerships of innovative SMEs in the Netherlands, we contribute to SME innovation literature by finding evidence that innovative biotech SMEs at risk of knowledge misappropriation are more likely to partner with PROs to not only gain new knowledge and capabilities, but also reduce the exposures of knowledge misappropriation risk. Moreover, we contribute by finding evidence that innovative SMEs at risk of legitimacy deficits are more likely to engage in affiliation and endorsement activities, i.e. non-product development activities, with PROs. This approach, therefore, contributes to literature on SME innovation partnerships by adding insights into partnerships and activities that certain innovative SMEs use to reduce exposure to involuntary knowledge misappropriation and legitimacy deficits.

The remainder of this paper consists of six parts. The following section reviews the characteristics of involuntary knowledge misappropriation and legitimacy deficits, arguing that biotechnology and cleantech SMEs are particularly prone to knowledge misappropriation and legitimacy deficits, respectively. This section continues by building two hypotheses on how SMEs at risk of these barriers overcome them. To examine these hypotheses, the next section presents our research methods and data. Subsequently, we present the results of binary and ordinal regression analyses. The final sections discuss the implication and limitation of our findings' ending in a conclusion.

\section{Theoretical Framework and Hypotheses}

\subsection{Involuntary knowledge misappropriation as a barrier to SME open innovation}

In his KBV of the firm, Grant [1996] points to collaboration, networking, and alliances between firms as an important factor for innovation success in knowledge intensive fields [Erden et al. (2014)]. KBV studies have shown that common and successful collaboration modes are based on partnerships with other firms that shorten innovation time, reduce risk and cost, and increase the flexibility of their operation [Hagedoorn (2002); Thorgren et al. (2012)]. Recent research posits that radical innovation from SMEs is positively affected by exploitative learning and by their knowledge sharing capability [Maes and Sels (2014)]. For instance, Mangematin et al. [2003] suggest that biotechnology SMEs may create bi-lateral contracts, especially with large industrial partners, to gain knowledge.

However, risk permeates situations of high uncertainty, especially in $R \& D$ management [Moehrle and Walter (2008)]. New knowledge, as an economic good, often depends on legal measures to ensure that non-paying consumers can be prevented from accessing it (excludability), while also providing availability to only those who do pay (rival). However, open innovation partnerships have been found to 
often lead to transaction costs and involuntary knowledge misappropriation by not fully ensuring excludability and restricting use [Mukherjee et al. (2013)]. Bouncken and Kraus [2013] suggest that while openly innovating may be helpful, not all partnerships are beneficial, that is, while entering into partnerships may facilitate positive knowledge spillover from larger organizations to SMEs, it also opens the door for opportunistic behaviors by collaborators to obtain knowledge outside of investing in resources [Parkhe (1993)]. According to Rogerson [1992], involuntary knowledge misappropriation is likely to occur in situations where new knowledge is non-excludable and non-rival, which creates an environment for opportunism. For example, biotechnology SMEs seek open innovation partnerships with larger pharmaceutical companies in order to reduce uncertainty of projects by sharing facilities, financial and human capital. Nevertheless, large pharmaceutical companies have a profit incentive such that acquiring new knowledge without investing resources reduces costs while increasing possibilities of successful drug development.

While innovative SMEs certainly seek excludability to insure themselves against the risk of knowledge misappropriation by concluding contracts with their innovation partners, it is inherently impossible to determine all features of new knowledge from its outset [Rogerson (1992), p. 777]. The reasons are twofold; first, when starting their collaboration, the involved parties may not foresee the necessity of writing certain provisions into the contract, because unpredictable events may occur in the future that change the significance of certain contractual provisions. Second, it is "too costly or too time consuming to write all the relevant details into a contract" [Malcomson (1997), p. 1917]. Consequently, it is difficult to prevent knowledge misappropriation, because it is inherently impossible to define ex ante which precise that intellectual property rights shall arise for the involved parties ex post. In addition, research finds that the risk of knowledge misappropriation is increased when the negotiation power and cooperation experience are limited [Dosi et al. (2006)], which are in turn related to the size of the firm [Rothaermel and Deeds (2004)]. Involuntary misappropriation may explain recent findings that the connections between network ties and firm performance are not always positive [Gronum et al. (2012)]. This is especially salient for SMEs with knowledge-based products and technologies that have relatively less bargaining power than large firms [Lavie (2007)].

\subsection{Biotechnology SMEs at risk of knowledge misappropriation}

Using biotechnology to develop new pharmaceuticals is one industry largely known for its high exposure to knowledge misappropriation. For one, the biotechnology industry has the highest alliance frequency among several industries characterized by high alliance activity [Hagedoorn (1993)] indicating the dispersed capabilities needed for product innovation in this industry [Hill and Rothaermel (2003)]. Nevertheless, product discovery and development is fraught with extremely high uncertainty. The discovery and development of new pharmaceuticals can be broken into a series of stages that can take cumulatively from 15 to 20 years [Giovannetti and Morrison (2000), pp. 46-47] and can cost over $\$ 500$ million for a single drug. 
Moreover, the odds of successful discovery and development of a molecule to drug are extremely low. For every 10000 compounds screened, 250 (2.5\%) make it into preclinical testing, and only five $(2 \%)$ enter clinical testing. Giovannetti and Morrison [2000] estimate that for every 10000 compounds screened, one drug will be approved implying a probability for a new commercialized drug being $0.01 \%$. Moreover, Lerner et al. [2003, p. 434] found that only $14 \%$ of alliances resulted in an approved drug, which indicates that, on the average, the majority of all biotechnology innovation projects will not result in commercialized products. Intense alliance activity combined with high uncertainty led Herrmann [2008, Chap. 2] to reiterate that it is also inherently difficult for biotech SMEs to protect from involuntary misappropriation. Walsh et al. [1995] empirically find that biotechnology SMEs in France, Britain and Canada were often used for knowledge creation and later exploited by large established organizations. Furthermore, Zucker et al. [1998, 2002], Niosi and Bas [2001], and Cooke [2008] all show that clusters of biotechnology ventures often suffer from knowledge misappropriation from large firms due to their open innovation strategies allowing for localized knowledge misappropriation opportunities. With their smaller resource base and size, biotechnology SMEs tend to have relatively less bargaining power than larger firms [Keupp and Gassmann (2009)]. In turn, SMEs risk being too dependent on large partners or losing crucial strategic information during "collaboration formation is to the possible detriment of their competitive advantage" [Chi (1994)].

\subsection{Partnerships with PROs to manage knowledge misappropriation risk}

Aside from writing contracts, biotech SMEs may be more likely to engage in innovation collaborations with organizations that have less or no incentive to appropriate knowledge: universities and research institutions [Li et al. (2008)]. Although PROs may be less important partners than the vertical chain of production (suppliers and clients), the contribution of PROs for new product development has been found to be significant, particularly for biotech SMEs. For example, Arundel and Geuna [2004] and Meyer-Krahmer and Schmoch [1998] underline the importance of collaborative research and informal contacts by suggesting that PRO partnerships reflect a possible catch-up to large firms [Narula (2004)]. Meanwhile, a number of papers have shown that SMEs draw upon the results of the research carried out in PROs to innovate. Mohnen and Hoareau [2003] found a positive relationship between the introduction of radical product innovations and the extent of reliance on PROs. Laursen and Salter [2004] found partial support for the hypothesis that firms that are more innovative, in terms of product innovations, are those that rely more on public sources.

On the other side, PROs have been found to engage in open innovation partnerships with SMEs in order to meet their own ends of high-quality research output [Roper and Hewitt-Dundas (2013)], and fulfilling third party (government) expectations of knowledge spillover through public-private partnerships [Katz and Martin (1997)]. Thus, they may be an intrinsic part of the knowledge-generation process, 
enabling knowledge co-creation by making explicit or tacit academic knowledge more visible. Moreover, they may be part of the PRO's knowledge exploitation or value-added generating activities, reflecting the contribution of research outputs to innovation [Katz and Martin (1997)].

We expect that SMEs at a high risk of involuntary knowledge misappropriation, such as biotechnology SMEs, will tend to select PRO partnerships to both create and protect dynamic capabilities [Perkmann and Walsh (2007)]. Collaborating with PROs as partners with similar incentives aligns with TCE. This theory highlights the role of trust amongst collaborators to mitigate apprehensions of opportunistic behavior [Adobor (2005)]. In other words, whereas open innovation partnerships are characterized by higher level of interdependencies between firms [Colombo et al. (2012)], which create knowledge misappropriation risks, interdependencies with universities and research institutes may reduce opportunism and hold-up problems in these cases [Niosi (1993)]. This is the case where partners such as university and research institutes have compatible incentives; biotech SMEs may use compatible relational capital as a signal of trustworthiness [Bjerregaard (2009); Inkpen and Tsang (2005)]. In fact, Bercovitz and Feldman [2007] find evidence that universities are preferred collaboration partners when a firm perceives conflicts over intellectual property. Recent findings by Brunetto and Farr-Wharton [2007], moreover, suggest that trust is a significant factor moderating the way SME owners/managers perceive the potential benefits of innovation networks. Lasagni [2012] finds that innovation performance is higher in SMEs that are proactive in strengthening their relationships with laboratories and research institutes in general. In light of biotech SMEs' demonstrated little bargaining power with larger firms and fewer resources to search for reliable business partnership to alleviate opportunism concerns, selecting partnerships with PROs will be a low-cost and low-risk pathway to basic knowledge. Accordingly, we hypothesize that

H1. Innovative SMEs at high risk of knowledge misappropriation are likely to select open innovation partnerships with PROs more than innovative SME at low risk.

\subsection{Legitimacy deficits as a barrier to innovation for SMEs}

In addition to knowledge misappropriation, a growing number of studies have also shown how the acquisition of organizational legitimacy is a key antecedent for obtaining scarce resources from external constituents which, in turn, are necessary for innovation [Human and Provan (2000); Rese and Baier (2011)]. Population ecology theory explains how the acquisition of key resources in part depends on how potential stakeholders understand (cognitive legitimacy) and accept (sociopolitical legitimacy) the activities of an SME at an industrial level [Deeds et al. (2004)]. Cognitive legitimacy refers to the spread of knowledge about similar organizations' practices, objectives, and technology [Aldrich and Ruef (2006)]. As an activity becomes familiar and taken-for-granted, time and resources are conserved as managers spend less time collectively educating and convincing potential partners 
[Freeman et al. (1983)]. Aldrich and Fiol [1994] describe how the diffusion of knowledge about how to use and manufacture personal computers in the 1970s and 1980s spreads to the use of PCs in homes and schools as an example of gaining cognitive legitimacy. Sociopolitical legitimacy, on the other hand, refers to the positive judgments of appropriateness and desirability of SME activities relative to norms and laws by key stakeholders, the general public, key opinion leaders, or government officials [Aldrich and Ruef (2006)]. Accordingly, the existing level of cognitive and sociopolitical legitimacy in the aggregate helps to facilitate partnership formation, resource flows, and legitimating innovations.

Innovative SMEs that operate in immature industries do so in contexts where cognitive and sociopolitical legitimacy is underdeveloped, highly politicized and contested [Aldrich and Fiol (1994)]. More specifically, population ecologists [Singh et al. (1986)] have attributed the slow introduction of SME innovation as related to the issue of "liability of newness" — deficits of awareness and comprehensibility (cognitive legitimacy) as well as a lack of acceptability and appropriateness by consumers and communities (sociopolitical legitimacy) [Freeman et al. (1983)]. SMEs operating in immature industries, especially those commercializing products based on new technologies, find it more necessary but more difficult to gain organizational legitimacy than those operating in mature industries because of these firms which have to learn new roles as social actors, coordinate new roles for employees, and deal with problems of mutual socialization of participants [Stinchcombe (1965)].

\subsection{Cleantech SMEs at risk of legitimacy deficits}

One such immature area particularly exposed to legitimacy deficits are SMEs developing cleantech innovations - new products with significantly lower impact on the natural environment than those they replace. Recent research shows that clean technology SMEs struggle to communicate financial, technological and environmental value to a wide variety of stakeholder groups [Farla et al. (2010); Geels and Kemp (2007); Jacobsson and Johnson (2000)]. Additionally, cleantech SMEs differ from other SMEs in that and they contribute to a collective good; they score better in terms of negative externalities. This implies that not all benefits of cleantech are of direct use to the consumer [Rennings (2000)]. Thus, for consumers, the reasons to select cleantech products are not only purely driven by rational economic motives, but also by normative, institutional factors. Since this leads to suboptimal diffusion patterns for cleantech innovation, governments often intervene and design policy schemes to make the adoption of cleantech innovations more interesting [Chappin et al. (2007)]. In their review, Montalvo [2008] suggests that cleantech SMEs face barriers related to public image and social legitimacy, such that entrepreneurs in emerging in cleantech industry have to interact with extremely skeptical external resource holders (suppliers, creditors, customers, etc.) [Gosens et al. (2015)], while competing with incumbent firms, that are committed to, invested in and advantaged by existing ways of doing things in a particular field [Smink et al. (2013)]. In their UK study, Dee et al. [2008] found that challenges with obtaining legitimacy have led to problems with attracting external finance, both with regard to securing funding 
for R\&D and taking the product to market (see also Fenton and Kanda [2016]). This is especially important since many of the areas of the cleantech sector (energy, transportation, green chemistry, etc.) have substantial financial barriers to entry [O'Rourke (2009)]. Uncertainty about industry standards and complex certification procedures was seen as inhibiting factors to legitimacy and thus the commercialization of clean technologies [de Lange (2016)].

Specifically for the Netherlands, where this research is undertaken, Parad et al. [2014] find that the country falls behind on commercializing cleantech innovation due to low cleantech manufacturing and a lack of publicly traded cleantech companies and IPOs. While the country has strong general innovation inputs and government policies supportive of cleantech, it has a low density of cleantech-focused funds and low innovation outputs [Emfel et al. (2011)]. A report by van den Berg and van der Slot [2009] uses a broad range of sources - e.g. business associations, newspapers and magazines, market research reports, company databases, government reports and websites - to count the density of Dutch cleantech companies to 266, which is small compared to neighboring Denmark and Germany. Almost half (46\%) had annual sales of less than EUR 2.5 million. In the leading countries, by contrast, (dedicated) cleantech companies are many more in number and many times larger. The small size and embryonic nature of most Dutch cleantech companies is an important reason for the relatively weak sales position of the Netherlands. By 2011, the Netherlands ranks 18th in sales by cleantech companies [van der Slot et al. (2011)]. Finally, Raspe et al. [2014] find that there seems to be a lack of urgency among Dutch companies (key clients to cleantech companies). Compared to those in Denmark and Germany, Dutch companies see reduced energy and material use as less important drivers of innovation, even though Dutch companies are relatively energy-intensive.

\subsection{Leveraging university partnerships to manage legitimacy deficits}

To overcome organizational legitimacy deficits, we hypothesize that cleantech SMEs, in addition to co-developing new knowledge, deploy a number of activities with PROs to generate acceptance and recognition for their industry [Suchman (1995)]. According to Zimmerman and Zeitz [2002], innovative SMEs operating in low legitimacy industries will use manipulating strategies to change existing norms and values [Starr and MacMillan (1990)]. One key manipulation strategy is through forging new affiliations and endorsements with high status organizations [David et al. (2012)]. Research in this area has suggested that affiliations with PROs help to convey legitimacy [Kirkels and Duysters (2010)] by creating the impression as a valid or worthy partners [Boulding et al. (1997); Winch and Courtney (2007)]. What is more, their highly legitimate standing can be seen from a European movement towards encouraging public research and private collaborations [Rothwell and Dodgson (1992)]. Affiliations act as a form of certification, substituting for reputation for SMEs in new industries [Brown (2012)] with highly legitimate PROs increasing the level of social capital, which can help SMEs acquire resources through the spread of positive referrals [Chollet et al. (2014)]. Endorsement from PROs also 
conveys legitimacy such that SMEs offer functional and innovative solutions via new product development. Innovative SMEs with low levels of legitimacy will likely avail themselves of any endorsements that enhance their firm and industry's legitimacy including positive media attention, tours, demonstrations, and guest lectures. In this respect, Bergek et al. [2008] and Suurs and Hekkert [2009] have highlighted the salient role of building legitimacy for cleantech innovations to counteract incumbent organizations strategically acting to de-legitimate them to protect market and organizational positions [Hekkert et al. (2007)].

Consequently, cleantech SMEs at risk of legitimacy deficits are more likely to seek legitimacy through publicly visible legitimation activities with public research organizations to increase their external perceptions of desirability, appropriateness, and acceptability [Geels and Verhees (2011); Kaganer et al. (2010)]. Accordingly, we hypothesize

H2. Innovative SMEs at a high risk of legitimacy deficits are more likely to strategically secure legitimacy by leveraging their PRO partnerships for affiliation and endorsements than innovative SMEs at a low risk of legitimacy deficits.

\section{Data and Analyses}

\subsection{Sample}

To examine our two hypotheses, we employ the "SME technology panel" (Technologische Bedrijvenpanel) created by the EIM Research and Policy Institute in the Netherlands. The resulting database contains systematic information, collected via computer-assisted telephone interviews in 2005, on various aspects and activities of overall 779 SMEs developing and commercializing technological innovations. SMEs in the database are defined as having fewer than 250 employees. As the purpose of the survey was to understand innovation barriers for innovative SMEs, screening questions limited the database to companies that have no more than 250 employees and that have shown to systematically innovate.

\subsection{Dependent variables}

\subsubsection{Innovation partnerships}

The EIM database includes one comprehensive set of indicators that captures all external innovation collaborations of the SMEs during the past three years. More precisely, the indictors measure whether or not an innovative SME has entered collaboration with at least one university, research institute, customer, supplier, competitor, or consultant during the past three years. In the survey, the question, for example, is stated as: "Over the past three years, which parties have your business collaborated with in innovation projects (select all that apply)?" All variables were measured on a scale from 0 to 2: 0 for no collaborations, 1 for collaborations for either home or abroad, and 2 for collaborations both home and abroad. While our main dependent variables are university and research institute partnerships, we have included other possible responses as dependent variables in order to test our 
hypotheses that biotech SMEs are more likely to collaborate with specifically PROs other than potential partnerships and other innovative SMEs.

\subsubsection{Organizational legitimacy strategies with PROs}

Second, the EIM database also includes information on the reasons why SMEs collaborated with PROs. In the survey, the question is stated as follows: "The next question is about your company's contacts with research institutes, universities, colleges and research organizations. What opportunities did apply to your business during last year?" Possible answers to the question about the aims of SME contacts with PROs include providing guest lectures, tours, and/or demonstrations, joint publications, joint R\&D projects, use of trainees, recruitment of new graduates, sharing facilities (laboratories, equipment, etc.), outsourcing research and advice, training of your employees, sharing employees. All responses are binary: 0 for "no" and 1 for "yes" responses.

Building from the previous section, we classify "providing guest lectures, tours, and demonstrations" and "joint publications" as distinctive affiliation and endorsement activities to gain legitimacy. Writing joint publications has been shown to provide the opportunity for SMEs to gain organizational legitimacy by developing new language and advertising the legitimate affiliations and endorsements with academic partners [Dowling et al. (1975)]. This is similar to SMEs that created connections and publications with Stanford University in the early days of the information technology industry for legitimacy reasons [Zimmerman and Zeitz (2002)]. Similarly, providing guest lectures, tours and demonstrations provides the opportunity to build affiliation and endorsement with PROs by publicizing connections with these highly legitimate actors [Lee et al. (2010)]. Here, the goal of legitimacy strategies is to tie the identity of the cleantech SME to a stable and highly legitimate partner [Aldrich and Ruef (2006)]. Other variables, joint R\&D projects, use of trainees, recruitment of new graduates, sharing facilities (laboratories, equipment, etc.), outsourcing research and advice, training of your employees, sharing employees, we classify as activities specifically for product development in line with KBV research [Niedergassel and Leker (2011)]. Again, while providing guest lectures and joining in joint publications are our key dependent variables, we included all the possible responses in the study to test our hypotheses.

\subsection{Independent variables}

We operationalize our key independent variables in line with industrial organization scholarship, which places emphasis on the industry effects, such as market structure and inherent characteristics, over firm heterogeneity [Mauri and Michaels (1998)]. To measure an SME's risk of knowledge appropriation, we selected SMEs active in biotechnology $(n=59),{ }^{\text {a }}$ as we have argued in the previous section, that

\footnotetext{
a Originally, the EIM panel distinguishes among seven technological areas in which SMEs are active, including one category on "bio- and food" technologies. Since it is unclear to what extent food technologies are comparable to biotechnologies, we considered the individual industry codes of all SMEs in this technological area (see van Koophandel [2005]) and excluded all food-technology firms. Consequently, the original sample of 88 "biotech and food" SMEs was reduced to 59 biotech SMEs.
} 
SMEs in this industry have been empirically found to be more at risk of knowledge misappropriation. Moreover, this measurement keeps with the common industrial organization scholarship that places emphasis on the industry effects, such as market structure and inherent characteristics, over firm heterogeneity [Mauri and Michaels (1998)]. Nevertheless, to further refine the measure of knowledge misappropriation in this area, an independent variable was created by interacting the biotechnology variable with responses to the question, "Is your company pursuing patents?" (measured $1=$ yes and $0=$ no). According to the European Patent Office [2016], Hyra [2010] and Silverman [2001], any patent that is filed must be published after 18 months - irrespective of whether or not the patent will actually be granted. It takes on average 3.6 years before a patent is granted or not [Dallimore (2009)], making biotech SMEs particularly susceptible to knowledge misappropriation for two reasons: (1) after 18 months, the patented knowledge will be made public - irrespective of whether, or not, a patent will be granted. (2) If no patent is granted, any other party can access and use this knowledge. We expect that innovative biotech SMEs pursuing patents are attempting to protect the knowledge created during $\mathrm{R} \& \mathrm{D}$ processes, but the difference between when an application is published and when it is granted creates risk of knowledge misappropriation. This interaction variable increases the precision of the measurement of knowledge misappropriation risk.

Secondly, to explain legitimacy strategies undertaken above, we have used recent empirical research to argue that clean technologies $(n=70)$ represent an industry characterized by a high risk of legitimacy deficits. Cleantech SMEs are defined as organizations that are active in alternative energy (e.g. wind, solar, biomass), soil treatment and environmental technologies. As discussed previously, numerous empirical studies suggest that cleantech SMEs face barriers related to public image and social legitimacy, which are linked to slowly changing social attitudes and values [Montalvo (2008); Gosens et al. (2015)], while competing with incumbent firms, that are committed to, invested in and advantaged by existing ways of doing things in a particular field [de Lange (2016); Dee et al. (2008); O'Rourke (2009); Smink et al. (2013)]. Measuring legitimacy continues to be a difficult task in organizational theory [Bozeman (1993); Suchman (1995); Vergne (2010)], with studies typically measuring the density of firms of similar types in certain industries or sectors or positive/negative publicity [Deeds et al. (2004)]. Since legitimacy deficits are a function of industry age and perceptions of legitimacy across stakeholders, we keep the unit of analysis at the industry level which is common in population ecology-led research [Singh et al. (1986)]. We follow recent evidence that Dutch cleantech companies are smaller, less in number, and receive more negative press than neighboring countries [van den Berg and van der Slot (2009); Raspe et al. (2014); Sengers et al. (2010); van der Slot et al. (2011)]. We argue that a binary variable allows us to broadly capture the legitimacy deficits (i.e. low density and smallness, as well as negative publicity) of the Dutch cleantech industry. Nevertheless, to further refine this measurement of legitimacy deficit risk, the cleantech variable was interacted with responses to the question "Does your company develop products or services based on new technology or new applications of existing technology?" 
(measured $1=$ yes, $0=$ no). Although organizational legitimacy is not purely based on technological or product maturity, previous research has shown that ambiguous new technologies in an environment of developing, incomplete knowledge of causeeffect relationships (e.g. renewable energy in Jacobsson and Johnson [2000]) means that the usual efficiency, output, or process criteria for evaluating organizational effectiveness are inappropriate. Instead, social criteria, such as legitimacy, are more often used to judge effectiveness [Deeds et al. (2004)]. In this sense, SMEs operating in an immature industry with new technology and new products provide a more refined measure of legitimacy deficit risk at the industry level.

\subsection{Control variables}

We included a number of control variables to test our hypotheses. First, we included information and communication technology (ICT, $n=125$ ) as a control group. Although not entirely necessary to test our hypotheses, including ICT as a control variable provides a point of comparison between SMEs at risk of knowledge misappropriation and legitimacy deficits with those that are not. Thus, we selected ICT because we expect that they are at low risk of both knowledge appropriation and legitimacy deficits at the industry level [Ayres and Williams (2004); Bettig (1996); Carlaw et al. (2006)].

Second, among all possible determinants that influence how SMEs cope with knowledge and legitimacy acquisition problems - other than a meticulous selection of R\&D partners and strategic interactions - age provides the strongest alternative explanatory factor. ${ }^{b}$ In line with research into firm age, younger SMEs can be expected to be more affected by knowledge misappropriation problems than older SMEs, because the latter have had more time to address this difficulty. For the same reason, younger SMEs are expected to be more affected by the legitimacy acquisition problem than older SMEs [Clegg et al. (2007); Elsbach and Sutton (1992)]. Firm age of an SME is coded as an age class based on the number of years since foundation. It should be noted that four outlier cases were included in the original database as three biotech ventures and one cleantech venture were older than 90 years. Since the inclusion of these outliers would have distorted the normality of distribution, we excluded these cases from the analyses.

Third, we controlled for the existence of a formal innovation strategy as another possible explanation of innovation partnerships with PROs. Bercovitz and Feldman [2007] find that innovation strategy influenced the level of involvement with university-based research. In a similar vein, this variable was controlled because we expect innovative SMEs that have a plan to innovate are more likely to collaborate with PROs as innovation partners than those that do not. Innovation strategy was asked through the question, "Does your business strategy consider...?" with "innovation" a possible answer (measure $1=$ yes, $0=$ no).

\footnotetext{
b In addition to firm age, we controlled for firm size (the number of employees) because we expected that smaller firms will be more at risk of knowledge misappropriation and legitimacy deficits because larger SMEs will have the capabilities to ward off unfavorable knowledge appropriation as well as being seen as a more legitimacy organization. However, firm age and size proved to be strongly correlated, so to avoid multi-collinearity, we included only firm age.
} 
Table 1. Descriptive statistics.

\begin{tabular}{|c|c|c|c|c|c|}
\hline & $N$ & Minimum & Maximum & Mean & Std. Deviation \\
\hline \multicolumn{6}{|l|}{ Dependent variables } \\
\hline University & 394 & 0 & 2 & 0.58 & 0.728 \\
\hline Research institutes & 394 & 0 & 2 & 0.44 & 0.620 \\
\hline Consumers & 394 & 0 & 2 & 1.01 & 0.729 \\
\hline Suppliers & 394 & 0 & 2 & 0.75 & 0.721 \\
\hline Competitors & 394 & 0 & 2 & 0.24 & 0.512 \\
\hline Consultants & 394 & 0 & 2 & 0.44 & 0.603 \\
\hline Use trainees & 394 & 0 & 1 & 0.57 & 0.496 \\
\hline Recruit graduates & 394 & 0 & 1 & 0.29 & 0.453 \\
\hline Joint R\&D projects & 394 & 0 & 1 & 0.45 & 0.498 \\
\hline Share facilities & 394 & 0 & 1 & 0.17 & 0.378 \\
\hline Outsourcing & 394 & 0 & 1 & 0.32 & 0.466 \\
\hline Training employees & 394 & 0 & 1 & 0.15 & 0.362 \\
\hline Guest lectures/tours & 394 & 0 & 1 & 0.26 & 0.440 \\
\hline Share employees & 394 & 0 & 1 & 0.12 & 0.322 \\
\hline Joint publications & 394 & 0 & 1 & 0.21 & 0.410 \\
\hline \multicolumn{6}{|l|}{ Independent variables } \\
\hline Biotech & 779 & 0 & 1 & 0.08 & 0.265 \\
\hline ICT & 779 & 0 & 1 & 0.30 & 0.460 \\
\hline Cleantech & 779 & 0 & 1 & 0.09 & 0.286 \\
\hline New product & 779 & 0 & 2 & 1.93 & 0.255 \\
\hline Patent & 382 & 0 & 1 & 0.38 & 0.487 \\
\hline Cleantech $\cdot$ NewProduct & 779 & 0 & 1 & 0.09 & 0.290 \\
\hline Biotech $\cdot$ Patent & 779 & 0 & 1 & 0.03 & 0.166 \\
\hline \multicolumn{6}{|l|}{ Control variables } \\
\hline Age classes & 750 & 1 & 4 & 2.16 & 1.095 \\
\hline Prod develop objective & 379 & 1 & 3 & 2.79 & 0.480 \\
\hline Innovation strategy & 263 & 0 & 1 & 0.91 & 0.289 \\
\hline
\end{tabular}

Finally, we control for the importance that an SME places on new product development through the question "How important are the following objectives at this time for your company?" (new product development measured as $1=$ not important, $2=$ somewhat important, and $3=$ very important). This control variable is taken into account because we can expect that a high importance on new product development will likely influence the type of contact with PROs. Therefore, this variable controls for alternative explanations of why an innovative SME may engage in guest lectures, joint publications, joint $R \& D$ projects, use of trainees, recruitment of new graduates, sharing facilities (laboratories, equipment, etc.), outsourcing research and advice, training of your employees, sharing employees. Taken together, these control variables allow us to get a more refined measure on the significance of our key independent variables.

\subsection{Analyses}

Four sets of regression analyses, ordinal and binary, were conducted to test the two hypotheses. To test our first hypothesis, ordinal regressions were used. According to McCullagh [1980], ordinal regression analysis is appropriate when trying to predict 
ordinal responses, because linear regression models assume that the outcome (dependent) variable is measured on an interval scale. Because this is not true for ordinal outcome variables, the simplifying assumptions on which linear regression relies are not satisfied, and thus the regression model may not accurately reflect the relationships in the data. To examine hypothesis 2 , binary regressions were used because the dependent variables are measured binomially. Both of these statistical techniques allow us to control for the effects of age, innovation strategy, and new product development as covariates. These two regressions are expressed mathematically as follows:

\section{Ordinal}

\begin{tabular}{ll|}
$\operatorname{link}\left(\gamma_{i j}\right)=\theta_{j}-\left[\beta_{1} x_{i 1}+\beta_{2} x_{i 2}+\cdots+\beta_{p} x_{i J}\right]$ \\
where & $\quad$ is the link function; \\
$\operatorname{link}()$ & is the cumulative probability of the $j$ th category for the $i$ th case; \\
$\gamma_{i j}$ & is the threshold for the $j$ th category; \\
$\theta_{j}$ & is the number of regression coefficients; \\
$P$ & are the values of the predictors for the $i$ th case; \\
$x_{i 1}, \ldots, x_{i p}$ & are regression coefficients. \\
$\beta_{1}, \ldots, \beta_{p}$ &
\end{tabular}

\section{Binary}

The relationship between $Z$ and the probability of the event of interest is described by this link function.

where,

$$
\pi_{i}=e z_{i 1}+e z_{i}=11+e-z_{i}
$$

or

$$
z_{i}=\log \left(\pi_{i 1}-\pi_{i}\right)
$$

$\pi_{i}$ is the probability the $i$ th case experiences the event of interest;

$z_{i}$ is the value of the unobserved continuous variable for the $i$ th case.

\section{Results}

\subsection{Selecting university partnerships to manage knowledge misappropriation risk}

Tables 2 and 3 report the results obtained from the ordinal regressions. In Table 2, the effects of an SME active in biotechnology, thus having a high risk of knowledge appropriation, have a significant and positive relationship with the choice of universities (at a 99\% confidence interval), research institutes (at a 90\% confidence 
Table 2. R\&D collaborations of SMEs with high knowledge-misappropriation risks (results of ordinal regressions).

\begin{tabular}{lcccccr}
\hline Independent & Dependent & $\begin{array}{c}\text { Research } \\
\text { institute }\end{array}$ & Consumers & Suppliers & Competitors & Consultants \\
\hline Biotech & $\mathbf{0 . 8 0 * * *}$ & $\mathbf{0 . 4 9 *}$ & $0.92^{* * *}$ & -0.13 & 0.23 & -0.34 \\
ICT & -0.01 & -0.31 & 0.01 & -0.05 & 0.09 & -0.43 \\
Age_class & -0.04 & 0.08 & -0.03 & $0.12^{*}$ & -0.04 & 0.14 \\
Innovation_strat & $0.43^{*}$ & 0.23 & $0.47^{*}$ & 0.37 & 0.11 & 0.36 \\
Psuedo $R$-squared & 0.07 & 0.04 & 0.08 & 0.02 & 0.01 & 0.05 \\
\hline
\end{tabular}

Notes: $* * *$ is significant at a 0.001 confidence level;

$* *$ is significant at a 0.05 confidence level;

$*$ is significant at a 0.10 confidence level.

Table 3. R\&D collaborations of SMEs with high knowledge-misappropriation risks (results of ordinal regressions with interaction).

\begin{tabular}{lclcccc}
\hline \multirow{2}{*}{ Independent } & Research & & & \\
institute & Consumers & Suppliers & Competitors & Consultants \\
\hline Biotech · Patent & $\mathbf{1 . 7 2 * * *}^{*}$ & $\mathbf{0 . 8 5 * *}$ & $0.87^{* * *}$ & -0.21 & 0.28 & -0.37 \\
ICT & 0.35 & 0.09 & 0.07 & -0.04 & 0.22 & $-0.42^{*}$ \\
Age_class & -0.15 & 0.05 & -0.05 & 0.11 & -0.06 & 0.13 \\
Innovation_strat & 0.38 & 0.03 & 0.42 & 0.36 & -0.13 & 0.35 \\
Psuedo $R$-squared & 0.16 & 0.31 & 0.10 & 0.02 & 0.01 & 0.04 \\
\hline
\end{tabular}

Notes: ${ }^{* * *}$ is significant at a 0.001 confidence level;

** is significant at a 0.05 confidence level;

$*$ is significant at a 0.10 confidence level.

interval) and consumers (at a 99\% confidence interval). Moreover, it shows that SMEs active in ICT have no similar and significant effects. In addition, we find that having a stated innovation strategy is a significant and positive predictor $(90 \%$ confidence interval) of whether an innovative SME will collaborate with universities for innovation. While age class is largely insignificant, results show that larger SMEs are more likely to collaborate with suppliers (90\% confidence interval). Finally, biotechnology SMEs are statically more likely to collaborate with consumers of new products other than innovative SMEs, which may allude to consumers also being another potential collaborator through which to both create and protect new knowledge. Biotechnology SMEs are shown to have no significant effect on the other dependent variables. These results indicate that biotech SMEs are more likely to collaborate with PROs, when controlling for firm age and stated innovation strategy, in line with our hypothesis 1 .

Table 3 includes the interaction term, biotechnology SME actively seeking patents, as the main independent variable. This variable was created to more precisely measure those firms exposed to knowledge misappropriation risks. In line with our hypothesis 1, we find that these SMEs are more likely to collaborate with PROs (99\% confidence with universities and 95\% confidence with research institutes) other than SMEs, particularly ICT, when controlling for age and stated innovation strategy. Again, biotechnology SMEs are significantly more likely to 
collaborate with consumers other than SMEs, while all other dependent variables remain insignificant.

Overall, we interpret these findings in support of hypothesis H1: innovative biotech SMEs, who are highly exposed to the risk of knowledge misappropriation, typically collaborate with PROs more than those firms not at risk of knowledge misappropriation, when controlled for innovation strategy and age class. Interestingly, innovative cleantech SMEs are also more likely to collaborate consumers other than SMEs, which may link to insights from the user-producer interaction literature [Moors et al. (2003)]. To conclude, our analyses of innovation partnerships provide empirical support that innovative SMEs using knowledge intensive biotechnologies seek collaboration with PROs other than potential collaborators and other innovative SMEs.

\subsection{Using university partnerships to manage legitimacy deficits}

Tables 4 and 5 report the results obtained from the binary regressions to test hypothesis 2. Table 4 shows that the effects of an SME active in cleantechnology, thus having a high risk of legitimacy deficits, have a significant and positive relationship with providing guest lectures, tours, and demonstrations (at a 95\% confidence interval), joint publications (at a 99\% confidence interval) when controlled for firm age and stated new product development objectives, in line with our hypothesis 2. Moreover, the table shows that innovative cleantech SMEs are significantly more likely to join in R\&D projects with PROs other than SMEs, particularly ICT, which is consistent with the KBV. Table 4 also shows that smaller SMEs and those seeking to develop new products are significant predictors of joining publications and joint R\&D projects with PROs. Moreover, no other dependent variables are statistically significant when being explained by the cleantech independent variable. These results support our second hypothesis by indicating that innovative cleantech SMEs, who are at risk of legitimacy deficits, are more likely to provide guest lectures, demonstrations, and tours and develop joint publications with PROs, when controlling for firm age and stated new product development objectives.

Table 5 includes the interaction term, innovative cleantech SMEs actively developing new products based on new technology, as the main independent variable. This variable was created to more precisely measure those firms exposed to legitimacy deficits at the industry level. In line with our hypothesis 2 , the table shows that these SMEs have a significant and positive relationship with providing guest lectures, tours, and demonstrations (at a 90\% confidence interval), and joint publications (at a 95\% confidence interval) when controlled for firm age and stated new product development objectives. Moreover, the table shows that innovative cleantech SMEs are significantly more likely to join in R\&D projects with PROs other than SMEs, particularly ICT who has a negative effect. Table 4 also shows that smaller SMEs and those seeking to develop new products are significant predictors of joining publications and joint R\&D projects with PROs.

In sum, these results support our second hypothesis by indicating that innovative cleantech SMEs, who are at risk of legitimacy deficits, are more likely to provide 

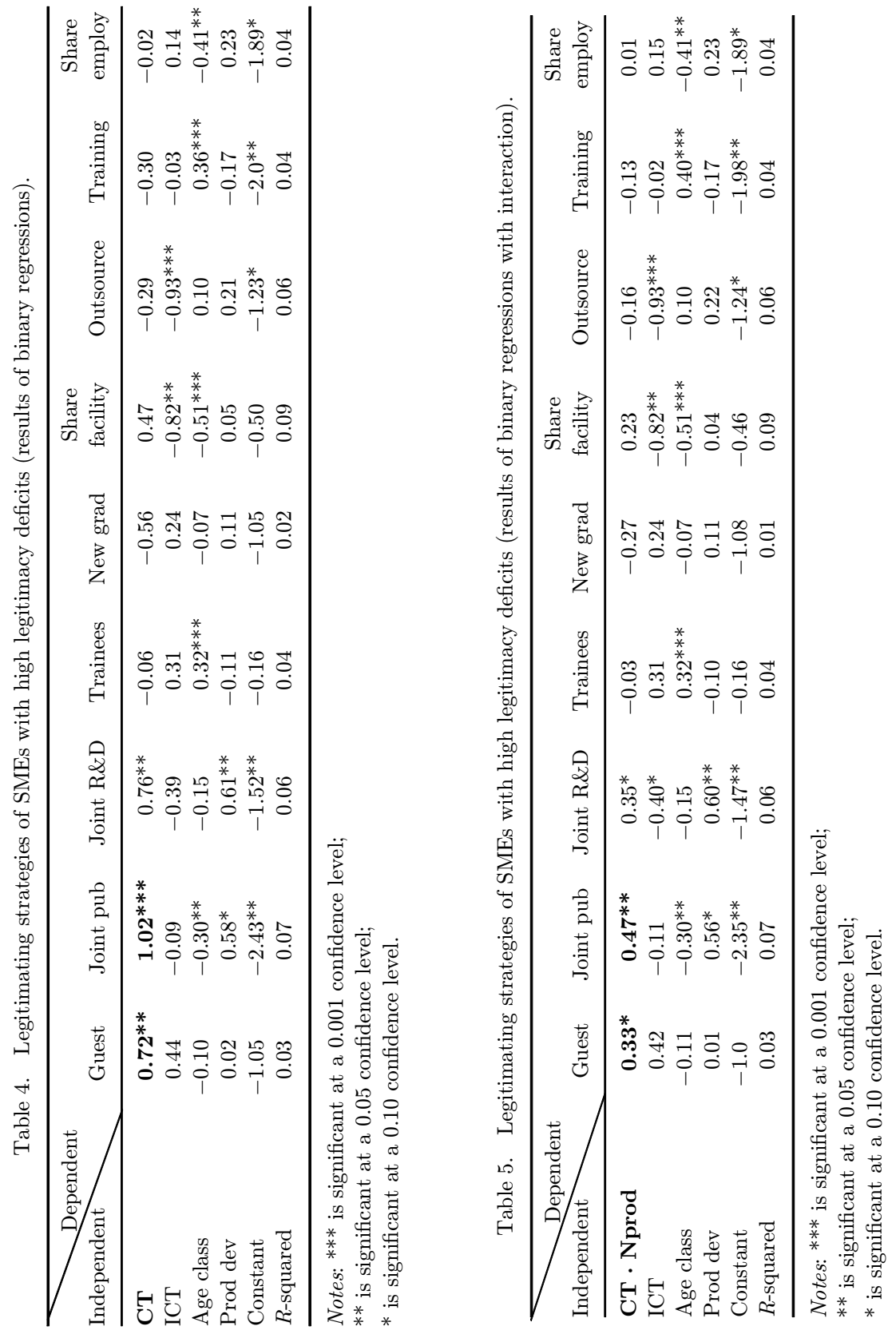
guest lectures, demonstrations, and tours and develop joint publications with PROs, when controlling for firm age and stated new product development objectives. Moreover, we find that cleantech SMEs are also likely to join in R\&D projects with PROs, which highlight the dual goals of learning and legitimacy through innovation partnerships. We conclude that despite the innovativeness of the sample, firm age, and specific aims to develop new products, innovative SMEs are likely to pursue legitimacy strategies through affiliation and endorsement with PROs when in a context of low legitimacy.

\section{Discussion}

\subsection{Implications}

The KBV of the firm highlights the salient role that collaborations between SMEs and PROs play for keeping abreast with technological change and product innovation success in knowledge intensive areas [Erden et al. (2014); Grant (1996)]. Where crucial knowledge is increasingly distributed across various firms, SMEs are moving towards open innovation strategies to obtain this knowledge [van de Vrande et al. (2009)]. Current research is particularly focused on how open innovation partnerships with PROs improve innovation performance over time by focusing on the absorptive capacity and knowledge co-production [Arundel and Geuna (2004); Meyer-Krahmer and Schmoch (1998)]. Nevertheless, research has largely overlooked how the exposure to knowledge misappropriation risk may also be a key predictor of university-industry collaborations. Employing TCE [Dyer and Chu (2003)], our findings suggest that innovative biotech SMEs aim to reduce this risk by being collaborating with PROs to reduce ex ante costs of knowledge misappropriation. By collaborating with trustworthy partners, these SMEs may be able to overcome their low bargaining power and resource dependency. This finding is similar to Bercovitz and Feldman [2007] who suggested that universities are likely to be chosen as innovation partnership in contexts where intellectual property continues to be an issue.

Importantly, this finding adds to theories of SME innovation partnership behavior. While current research mainly views public-private partnerships as a way to gain complementary knowledge necessary for innovation [Perkmann and Walsh (2007)], partnerships based on risk management also explain partnership behavior. The growth of public-private innovation partnerships documented by Bovaird [2004] may not be only for knowledge creation, but also for knowledge protection. Accordingly, this adds to theory of SME open innovation through the lens of risk mitigation as an alternative explanation for the growth and motivations for publicprivate partnerships.

In addition, we draw from population ecology to hypothesize that the acquisition of key resources needed for successful innovation in part depends on cognitive and sociopolitical legitimacy of the SME [Aldrich and Fiol (1994)]. Despite organizational legitimacy being a foundation concept in organizational studies for over two decades, it has been largely absent in explaining SME innovation partnership behavior. Echoing Cheng [2010], we argue that PROs are both crucial external 
evaluators as well as legitimizing partners [Dowling et al. (1975)]. Again, adding to literature on SME public-private innovation partnerships, our findings point to the number of roles research organizations may have outside of innovation research and development. Firstly, PROs likely provide a context where legitimacy deficient SMEs can legitimate themselves in the eyes of important researchers through affiliation and endorsement. As researchers "buy into" an SMEs' innovation objectives, the more likely they will be in committing resources towards joint innovative projects on average. Secondly, organizational legitimacy via PROs through endorsements allows SMEs to integrate themselves into their social environment [Aldrich and Ruef (2006)]. This lends itself to a growing external organizational legitimacy necessary to build awareness and acceptability of products in immature industries. In fact, research by Thompson et al. [2015] shows how small firms using new renewable energy technologies, such as bio-energy, face and overcome a number of legitimacy deficiencies inherent in immature industries. The findings that legitimacy deficient SMEs are likely to engage in legitimacy building activities to integrate themselves into their social environment add to the theory of open innovation by augmenting the knowledge-based perspective. To date, little SME research which acknowledges the role of organizational legitimacy is used for explaining SME innovation behavior. Hence, we highlight this vital area and offer measurable variables that capture legitimacy strategies within public-private partnerships that have been absent in the extant literature.

\subsection{Limitations and opportunities for future research}

Like most studies, our research is not without limitations. First, we operationalized knowledge misappropriation at the industry level, and improved upon this with interaction terms (pursuing patents) to capture knowledge misappropriation risks. In line with industrial organization scholars, who have long treated the industry as the unit of analysis by proposing that market structure, leads to similar problems and a convergence of successful strategies over time, we concede that firm-level variables would help to refine the measurement. One such firm-level variable, however, which was not included in our survey data, would be the experiences of the firm with open innovation (in terms of years or number of collaborations) and experiences with knowledge misappropriation cases (in terms of legal issues, or subjective viewpoints). Future research that measures knowledge misappropriation at the firm level will help to further refine our findings that PROs are a possible setting for both creation and protection of new knowledge. Similarly, we operationalized legitimacy deficits at the industry level, and improved upon this measure with an interaction term (new product/new technology) to capture those SME exposed to risks of low legitimacy and liability of newness. Future research that attempts to measure legitimacy deficits at the firm level would be insightful, however this has proven to be a particularly challenging exercise due in part on its representation based on multiple stakeholder impressions. One could survey a particular representation based on a single stakeholder, such as PROs, however this would still 
exclude potential target effects of strategies aimed at building in the legitimacy of the immature industry.

Secondly, we acknowledge that even though the EIM database is a comprehensive, large-scale, and randomly selected source of information, we generalized our findings using a logic of proximal similarity. Specifically, we argue that different industrial contexts other than biotech and cleantech but that share degrees of low excludability of knowledge, non-rival new knowledge, and legitimacy deficits will also be more likely to partner with PROs. We envision future research that explores this implicit theoretical gradient of similarity in other contexts. However, we realize here that this remains a question for future research.

Thirdly, we acknowledge that there may be other reasons as to why innovative SMEs in this study were oriented towards PROs. Dahlander and McFarland [2013] argue shared organizational foci, shared traits and interests, tie advantages from popularity, tie reinforcement from third parties, tie strength and multiplicity, and the instrumental returns from the products of ties are all reasons why organizations form lasting ties. We have argued that PROs and innovative SMEs share foci, interests, reinforcement and returns in terms of knowledge and legitimacy. In our model, we attempted to control for an alternative explanation why innovative biotech SMEs may collaborate more with PROs by including the variable "written innovation strategy" as a covariate. While this controls for many knowledge-based reasons why an SME would collaborate with a PRO over other potential partners and other innovative SMEs, more alternative variables could parse out the extent to which partnerships are based on creation or protection of new knowledge. Future research could, for example, design a survey that includes knowledge-based questions as well as intellectual property protection questions. In a similar vein, future research that includes a more comprehensive set of variables to measure endorsement and affiliation activities for legitimation would help to distinguish between activities with PROs aimed at developing new knowledge and developing organizational legitimacy.

Finally, our paper rests on the assumption that SMEs are not pre-conditioned in their choices of their R\&D collaboration partners. In other words, we assume that they are free to choose whether to partner with PROs, commercial partners or both in their R\&D projects. Hence, we assume that there are no pre-existing inter-organizational ties that may make it easier for SMEs to collaborate with PROs than with private actors or vice versa. And yet, it would certainly be worthwhile to explore in future research the extent to which such inter-organizational ties pre-exist and, if they do, limit or condition the choice of R\&D collaboration partners for SMEs. Thus, this future research would refine the findings from our study by including sets of preexisting inter-organizational ties as independent variables, which combined with measures of knowledge misappropriation and legitimacy deficit risk, could further improve our understanding of SMEs' choices of R\&D partners.

\section{Conclusions}

In this study, we have examined how collaborations with PROs help SMEs cope with two risks of open innovation: increased involuntary knowledge misappropriation and 
legitimacy deficiency. Our analyses using a comprehensive dataset on innovative SMEs have shown that SMEs "at risk" of involuntary knowledge misappropriation behave differently than SMEs less "at risk". Overall, these SMEs are more likely to select PROs to ensure knowledge retention and mitigate appropriability. These findings are of interest to SME innovation scholars as they suggest another explanation for growing prevalence of public-private partnerships. Specifically, innovative SMEs may not only select partnerships based on potential for knowledge development leading to new products, but also certain partners have equivalent incentives that reduce knowledge misappropriation risks. Furthermore, our analyses indicate that innovative SMEs that lack organizational legitimacy collectively pursue affiliation and endorsement legitimating strategies with PROs. These findings are of interest to SME innovation scholars attempting to explain SME partnership behavior that seemingly is only tangentially related to new product development activities. Specifically, we move attention from a focus on partnerships for solely the co-production of knowledge motivations towards an alternative explanation that the motivation of partnering to garner an external perception of organizational legitimacy.

\section{References}

Adobor, H. (2005). Trust as sensemaking: The microdynamics of trust in interfirm alliances. Journal of Business Research, 58, 3: 330-337.

Aldrich, H. E. and Fiol, C. M. (1994). Fools rush in? The institutional context of industry creation. Academy of Management Review, 19, 4: 645-670.

Aldrich, H. E. and Ruef, M. (2006). Organizations Evolving, 2nd edn. Sage, London.

Arundel, A. and Geuna, A. (2004). Proximity and the use of public science by innovative European firms. Economics of Innovation and New Technology, 13, 6: 559-580. Available at: http://doi.org/10.1080/1043859092000234311.

Ayres, R. U. and Williams, E. (2004). The digital economy: Where do we stand? Technological Forecasting and Social Change, 71, 4: 315-339.

Bercovitz, J. E. L. and Feldman, M. P. (2007). Fishing upstream: Firm innovation strategy and university research alliances. Research Policy, 36, 7: 930-948. Available at: http:// doi.org/10.1016/j.respol.2007.03.002.

Bergek, A., Jacobsson, S. and Sandén, B. A. (2008). "Legitimation" and "development of positive externalities": Two key processes in the formation phase of technological innovation systems. Technology Analysis \& Strategic Management, 20, 5: 575-592. Available at: http://doi.org/10.1080/09537320802292768.

Bettig, R. V. (1996). Copyrighting Culture: The Political Economy of Intellectual Property. Westview Press, Chicago.

Bjerregaard, T. (2009). Universities-industry collaboration strategies: A micro-level perspective. European Journal of Innovation Management, 12, 2: 161-176. Available at: http:// doi.org/10.1108/14601060910953951.

Boulding, W., Morgan, R. and Staelin, R. (1997). Pulling the plug to stop the new product drain. Journal of Marketing Research, 34, 1: 164-176.

Bouncken, R. B. and Kraus, S. (2013). Innovation in knowledge-intensive industries: The double-edged sword of coopetition. Journal of Business Research, 66, 10: 2060-2070.

Bovaird, T. (2004). Public-private partnerships: From contested concepts to prevalent practice. International Review of Administrative Sciences, 70, 2: 199-215. 
Bozeman, B. (1993). Understanding the roots of publicness. The Legitimate Corporation, ed. B. Bozeman. Blackwell, Cambridge, Massachusetts, pp. 63-81.

Bridwell-Mitchell, E. N. and Mezias, S. J. (2012). The quest for cognitive legitimacy: Organizational identity crafting and internal stakeholder support. Journal of Change Management, 12, 2: 1-19. Available at: http://doi.org/10.1080/14697017.2011.645053.

Brown, A.-K. (2012). Trapped by Narcissism: A disillusioned dutch society. Macalester International, 30, 1: 7.

Brunetto, Y. and Farr-Wharton, R. (2007). The moderating role of trust in SME owner/ managers' decision-making about collaboration. Journal of Small Business Management, 45, 3: 362-387. Available at: http://doi.org/10.1111/j.1540-627X.2007.00218.x.

Carlaw, K., Oxley, L., Walker, P., Thorns, D. and Nuth, M. (2006). Beyond the hype: Intellectual property and the knowledge society/knowledge economy. Journal of Economic Surveys, 20, 4: 633-690.

Chappin, M. M. H., Meeus, M. T. H., Hekkert, M. P. and Vermeulen, W. J. V. (2007). Dynamic perspective on the relation between environmental policy and eco-efficiency: The case of wastewater treatment, waste and energy efficiency in the Dutch paper and board industry. Progress in Industrial Ecology, An International Journal, 4, 1/2: 19.

Cheng, H.-L. (2010). Seeking knowledge or gaining legitimacy? Role of social networks on new practice adoption by OEM suppliers. Journal of Business Research, 63, 8: 824-831.

Chi, T. (1994). Trading in strategic resources: Necessary conditions, transaction cost problems, and choice of exchange structure. Strategic Management Journal, 15, 4: 271-290.

Chiang, Y. H. and Hung, K. P. (2010). Exploring open search strategies and perceived innovation performance from the perspective of interorganizational knowledge flows. $R \mathscr{E} D$ Management, 40, 3: 292-299.

Chollet, B., Géraudel, M. and Mothe, C. (2014). Generating business referrals for SMEs: The contingent value of CEOs' social capital. Journal of Small Business Management, 52, 1: 79-101. Available at: http://doi.org/10.1111/jsbm.12034.

Clegg, S. R., Rhodes, C. and Kornberger, M. (2007). Desperately seeking legitimacy: Organizational identity and emerging industries. Organization Studies, 28, 4: 495-513. Available at: http://doi.org/10.1177/0170840606067995.

Colombo, M. G., Laursen, K., Magnusson, M. and Rossi-Lamastra, C. (2012). Introduction: Small business and networked innovation: Organizational and managerial challenges. Journal of Small Business Management, 50, 2: 181-190. Available at: http://doi.org/ 10.1111/j.1540-627X.2012.00349.x.

Cooke, P. (2008). The evolution of biotechnology in bioregions and their globalisation. International Journal of Biotechnology, 10, 5: 476-495.

Dahlander, L. and McFarland, D. A. (2013). Ties that last tie formation and persistence in research collaborations over time. Administrative Science Quarterly, 58, 1: 69-110.

Dallimore, G. (2009). European patent applications filed and patents granted from 1997 to 2008. Annual Report 2009. European Patent Office.

David, R. J., Sine, W. D. and Haveman, H. A. (2012). Seizing opportunity in emerging fields: How institutional entrepreneurs legitimated the professional form of management consulting. Organization Science, 7039: 1-22. Available at: http://doi.org/10.1287/ orsc.1120.0745.

de Lange, D. E. (2016). Legitimation strategies for clean technology entrepreneurs facing institutional voids in emerging economies. Journal of International Management, 22, 4: 403-415. Available at: http://doi.org/10.1016/j.intman.2016.06.002.

Dee, N., Ford, S. J. and Garnsey, E. (2008). Obstacles to commercialization of clean technology innovations from UK ventures. Sustainable Innovation and Entrepreneurship. New Perspectives in Research on Corporate Sustainability, eds. R. Wustenhagen, J. Hamschmidt, S. Sharma and M. Starik, Edward Elgar, Cheltenham, pp. 97-118. 
Deeds, D. L., Mang, P. Y. and Frandsen, M. L. (2004). The influence of firms' and industries' legitimacy on the flow of capital into high-technology ventures. Strategic Organization, 2, 1: $9-34$.

Dosi, G., Malerba, F., Ramello, G. B. and Silva, F. (2006). Information, appropriability, and the generation of innovative knowledge four decades after Arrow and Nelson: An introduction. Industrial and Corporate Change, 15, 6: 891-901.

Dowling, J., Pfeffer, J. and Press, C. (1975). Organizational legitimacy social values and organizational behavior. The Pacific Sociological Review, 18, 1: 122-136.

Dyer, J. H. and Chu, W. (2003). The role of trustworthiness in reducing transaction costs and improving performance: Empirical evidence from the United States, Japan, and Korea. Organization Science, 14, 1: 57-68.

Elsbach, K. D. K. and Sutton, R. I. (1992). Acquiring organizational legitimacy through illegitimate actions: A marriage of institutional and impression management theories. Academy of Management Journal, 35, 4: 699-738.

Emfel, M., Kratt, L., van den Berg, W. and van der Slot, A. (2011). Enabling the Transition Climate Innovation Systems for a Low-Carbon Future, World Wildlife Foundation (WWF), Washington, DC.

Erden, Z., Klang, D., Sydler, R. and von Krogh, G. (2014). Knowledge-flows and firm performance. Journal of Business Research, 67, 1: 2777-2785.

European Patent Office. (2016). European Patent Convention. Munich, Germany.

Fabrizio, K. R. (2009). Absorptive capacity and the search for innovation. Research Policy, 38, 2: 255-267.

Farla, J., Alkemade, F. and Suurs, R. A. A. (2010). Analysis of barriers in the transition toward sustainable mobility in the Netherlands. Technological Forecasting and Social Change, 77, 8: 1260-1269.

Fenton, P. and Kanda, W. (2016). Barriers to the diffusion of renewable energy: Studies of biogas for transport in two European cities. Journal of Environmental Planning and Management, 60, 4: 1-18. Available at: http://doi.org/10.1080/09640568.2016.1176557.

Fontana, R., Geuna, A. and Matt, M. (2006). Factors affecting university-industry R\&D projects: The importance of searching, screening and signalling. Research Policy, 35, 2: 309-323. Available at: http://doi.org/10.1016/j.respol.2005.12.001.

Freeman, J., Carroll, G. R. and Hannan, M. T. (1983). The liability of newness: Age dependence in organizational death rates. American Sociological Review, 48, 5: 692-710.

Geels, F. W. and Kemp, R. (2007). Dynamics in socio-technical systems: Typology of change processes and contrasting case studies. Technology in Society, 29, 4: 441-455.

Geels, F. W. and Verhees, B. (2011). Cultural legitimacy and framing struggles in innovation journeys: A cultural-performative perspective and a case study of Dutch nuclear energy (1945-1986). Technological Forecasting and Social Change, 78, 6: 910-930.

Giovannetti, G. T. and Morrison, S. W. (2000). Convergence: The Biotechnology Industry Report. Palo Alto, Ernst and Young, CA.

Gosens, J., Lu, Y. and Coenen, L. (2015). The role of "Technological Innovation Systems" for cleantech in emerging economies. Journal of Cleaner Production, 86: 378-388. Available at: http://doi.org/10.1016/j.jclepro.2014.08.029.

Grant, R. (1996). Toward a knowledge-based theory of the firm. Strategic Management Journal, 17: 109-122.

Gronum, S., Verreynne, M.-L. and Kastelle, T. (2012). The role of networks in small and medium-sized enterprise innovation and firm performance. Journal of Small Business Management, 50, 2: 257-282. Available at: http://doi.org/10.1111/j.1540627X.2012.00353.x.

Hagedoorn, J. (1993). Understanding the rationale of strategic technology partnering: Interorganizational modes of cooperation and sectoral differences. Strategic Management Journal, 14, 5: 371-385. 
Hagedoorn, J. (2002). Inter-firm R\&D partnerships: An overview of major trends and patterns since 1960. Research Policy, 31, 4: 477-492.

Hall, J., Matos, S., Silvestre, B. and Martin, M. (2011). Managing technological and social uncertainties of innovation: The evolution of Brazilian energy and agriculture. Technological Forecasting and Social Change, 78, 7: 1147-1157. Available at: http://doi.org/ http://dx.doi.org/10.1016/j.techfore.2011.02.005.

Hannan, M. and Carroll, G. R. (1992). Dynamics of Organizational Populations: Density, Legitimation, and Competition. Oxford University Press, New York.

Hannan, M. T. and Freeman, J. (1977). The population ecology of organizations. American Journal of Sociology, 82, 5: 929-964.

Hekkert, M. P., Harmsen, R. and de Jong, A. (2007). Explaining the rapid diffusion of Dutch cogeneration by innovation system functioning. Energy Policy, 35, 9: 4677-4687.

Hill, C. W. L. and Rothaermel, F. T. (2003). The performance of incumbent firms in the face of radical technological innovation. Academy of Management Review, 28, 2: 257-274.

Human, S. E. and Provan, K. G. (2000). Legitimacy building in the evolution of small-firm multilateral networks: A comparative study of success and demise. Administrative Science Quarterly, 45, 2: 327-365.

Hyra, C. D. (2010). How to stop your inventions from being stolen: The three-step invention protection plan. Retrieved from http://hyraip.com/2009/11/three-step-inventionprotection-plan/. Report, Reston Virginia Attorneys. Washington, DC.

Inkpen, A. C. and Tsang, E. W. K. (2005). Social capital, networks, and knowledge transfer. Academy of Management Review, 30: 146-165. Available at: http://doi.org/10.5465/ amr.2005.15281445.

Jacobsson, S. and Johnson, A. (2000). The diffusion of renewable energy technology: An analytical framework and key issues for research. Energy Policy, 28, 9: 625-640.

Kaganer, E., Pawlowski, S. D. and Wiley-Patton, S. (2010). Building legitimacy for IT innovations: The case of computerized physician order entry systems. Journal of the Association of Information Systems, 11, 1: 1-33.

Kale, P., Singh, H. and Perlmutter, H. (2000). Learning and protection of proprietary assets in strategic alliances: Building relational capital. Strategic Management Journal, 1: 217-237.

Katz, J. S. and Martin, B. R. (1997). What is research collaboration. Research Policy, 26, 1 : 1-18. Available at: http://doi.org/10.1016/S0048-7333(96)00917-1.

Keupp, M. M. and Gassmann, O. (2009). Determinants and archetype users of open innovation. REDD Management, 39, 4: 331-341.

Kirkels, Y. and Duysters, G. (2010). Brokerage in SME networks. Research Policy, 39, 3: 375385. Available at: http://doi.org/http://dx.doi.org/10.1016/j.respol.2010.01.005.

Lasagni, A. (2012). How can external relationships enhance innovation in SMEs? New evidence for Europe. Journal of Small Business Management, 50, 2: 310-339. Available at: http://doi.org/10.1111/j.1540-627X.2012.00355.x.

Laursen, K. and Salter, A. (2004). Searching high and low: What types of firms use universities as a source of innovation? Research Policy, 33, 8: 1201-1215.

Lavie, D. (2007). Alliance portfolios and firm performance: A study of value creation and appropriation in the U.S. software industry. Strategic Management Journal, 28: 11871212. Available at: http://doi.org/10.1002/smj.

Lee, S., Park, G., Yoon, B. and Park, J. (2010). Open innovation in SMEs - An intermediated network model. Research Policy, 39, 2: 290-300. Available at: http://doi.org/ http://dx.doi.org/10.1016/j.respol.2009.12.009.

Lerner, J., Shane, H. and Tsai, A. (2003). Do equity financing cycles matter? Evidence from biotechnology alliances. Journal of Financial Economics, 67, 3: 411-446.

Li, D., Eden, L., Hitt, M. A. and Ireland, R. D. (2008). Friends, acquaintances, or strangers? Partner selection in R\&D alliances. Academy of Management Journal, 51, 2: 315-334. Available at: http://doi.org/10.1002/smj. 
Low, B. and Johnston, W. J. (2010). Organizational network legitimacy and its impact on knowledge networks: The case of China's TD-SCDMA mobility technology. Journal of Business and Industrial Marketing, 25, 6: 468-477.

Maes, J. and Sels, L. (2014). SMEs' radical product innovation: The role of internally and externally oriented knowledge capabilities. Journal of Small Business Management, 52, 1: 141-163. Available at: http://doi.org/10.1111/jsbm.12037.

Malcomson, J. M. (1997). Contracts, hold-up, and labor markets. Journal of Economic Literature, 35, 4: 1916-1957.

Mangematin, V., Lemarié, S., Boissin, J.-P., Catherine, D., Corolleur, F., Coronini, R. and Trommetter, M. (2003). Development of SMEs and heterogeneity of trajectories: The case of biotechnology in France. Research Policy, 32, 4: 621-638. Available at: http://doi.org/ http://dx.doi.org/10.1016/S0048-7333(02)00045-8.

Mauri, A. J. and Michaels, M. P. (1998). Firm and industry effects within strategic management: An empirical examination. Strategic Management Journal, 19: 211-219. Available at: http://doi.org/10.1002/(SICI)1097-0266(199803)19:3<211::AID-SMJ947>3.0.CO;2-T.

McCullagh, P. (1980). Regression models for ordinal data. Journal of the Royal Statistical Society. Series B (Methodological), 42, 2: 109-142.

Meyer-Krahmer, F. and Schmoch, U. (1998). Science-based technologies: University-industry interactions in four fields. Research Policy, 27, 8: 835-851.

Meyer, J. W. and Rowan, B. (1977). Institutionalized organizations: Formal structure as myth and ceremony. American Journal of Sociology, 83, 2: 340-363.

Moehrle, M. G. and Walter, L. (2008). Risk and uncertainty in R\&D management. RED Management, 38, 5: 449-451. Available at: http://doi.org/10.1111/j.1467-9310.2008.00536.x.

Mohnen, P. and Hoareau, C. (2003). What type of enterprise forges close links with universities and government labs? Evidence from CIS 2. Managerial and Decision Economics, 24, 2-3: 133-145.

Montalvo, C. (2008). General wisdom concerning the factors affecting the adoption of cleaner technologies: A survey 1990-2007. Journal of Cleaner Production, 16, 1: 7-13. Available at: http://doi.org/10.1016/j.jclepro.2007.10.002.

Moors, E., Smits, R., Enzing, C. and van der Giessen, A. (2003). User-producer interactions in functional genomics innovations. Innovation: Management, Policy $\&$ Practice, 5, 2-3: $120-143$.

Mukherjee, D., Gaur, A. S., Gaur, S. S. and Schmid, F. (2013). External and internal influences on R\&D alliance formation: Evidence from German SMEs. Journal of Business Research, 66, 11: 2178-2185.

Narula, R. (2004). R\&D collaboration by SMEs: New opportunities and limitations in the face of globalisation. Technovation, 24, 2: 153-161.

Niedergassel, B. and Leker, J. (2011). Different dimensions of knowledge in cooperative R\&D projects of university scientists. Technovation, 31, 4: 142-150.

Niosi, J. (1993). Strategic partnerships in Canadian advanced materials. R\&D Management, 23, 1: 17-28. Available at: http://doi.org/10.1111/j.1467-9310.1993.tb01211.x.

Niosi, J. and Bas, T. G. (2001). The competencies of regions - Canada's clusters in biotechnology. Small Business Economics, 17, 1-2: 31-42.

O'Rourke, A. R. (2009). The Emergence of Cleantech. Yale University, New Haven.

Parad, M., Henningsson, S., Currás, T. and Youngman, R. (2014). The Global Cleantech Innovation Index 2014. Report, Cleantech Group and WWF. Washington, D.C.

Parkhe, A. (1993). Strategic alliance structuring: A game theoretic and transaction cost examination of interfirm cooperation. Academy of Management Journal, 36, 4: 794-829.

Perkmann, M. and Walsh, K. (2007). University-industry relationships and open innovation: Towards a research agenda. International Journal of Management Reviews, 9, 4: 259-280. Available at: http://doi.org/10.1111/j.1468-2370.2007.00225.x. 
Raspe, O., van den Berge, M., Brandes, L., van der Esch, S., Notenboom, J. and Reudink, M. (2014). Green Gains - In Search of Opportunities for the Dutch Economy. The Hague, Netherlands.

Rennings, K. (2000). Redefining innovation - Eco-innovation research and the contribution from ecological economics. Ecological Economics, 32, 2: 319-332.

Rese, A. and Baier, D. (2011). Success factors for innovation management in networks of small and medium enterprises. RED Management, 41, 2: 138-155.

Rogerson, W. P. (1992). Contractual solutions to the hold-up problem. The Review of Economic Studies, 59, 4: 777-793.

Roper, S. and Hewitt- Dundas, N. (2013). Catalysing open innovation through publiclyfunded R\&D: A comparison of university and company-based research centres. International Small Business Journal, 31, 3: 275-295. Available at: http://doi.org/10.1177/ 0266242612454671.

Rothaermel, F. T. and Deeds, D. L. (2004). Exploration and exploitation alliances in biotechnology: A system of new product development. Strategic Management Journal, 25, 3: 201-221. Available at: http://doi.org/10.1002/smj.376.

Rothwell, R. and Dodgson, M. (1992). European technology policy evolution: Convergence towards SMEs and regional technology transfer. Technovation, 12, 4: 223-238.

Sawers, J. L., Pretorius, M. W. and Oerlemans, L. A. G. (2008). Safeguarding SMEs dynamic capabilities in technology innovative SME-large company partnerships in South Africa. Technovation, 28, 4: 171-182. Available at: http://doi.org/10.1016/j.technovation.2007.09.002.

Sengers, F., Raven, R. P. J. M. and Van Venrooij, A. (2010). From riches to rags: Biofuels, media discourses, and resistance to sustainable energy technologies. Energy Policy, 38, 9: 5013-5027.

Silverman, A. B. (2001). Can publishing your U.S. patent application reveal confidential information? JOM, 53, 9: 64 .

Singh, J. V., Tucker, D. J. and House, R. J. (1986). Organizational legitimacy and the liability of newness. Administrative Science Quarterly, 31, 2: 171-193.

Smink, M. M., Hekkert, M. P. and Negro, S. O. (2013). Keeping sustainable innovation on a leash? Exploring incumbents' institutional strategies. Business Strategy and the Environment, 24, 2: 86-101. Available at: http://doi.org/10.1002/bse.1808.

Starr, J. and MacMillan, I. C. (1990). Resource cooptation via social contracting: Resource acquisition strategies for new ventures. Strategic Management Journal, 11: 79-92.

Stinchcombe, A. L. (1965). Social structure and organizations. Handbook of Organizations, Rand McNally, Chicago, pp. 142-193.

Suchman, M. C. (1995). Managing legitimacy: Strategic and institutional approaches. Academy of Management Review, 20, 3: 571-610.

Suurs, R. A. A. and Hekkert, M. P. (2009). Competition between first and second generation technologies: Lessons from the formation of a biofuels innovation system in the Netherlands. Energy, 34, 5: 669-679. Available at: http://doi.org/DOI:10.1016/j.energy.2008.09.002.

Teece, D. J. (1986). Profiting from technological innovation: Implications for integration, collaboration, licensing and public policy. Research Policy, 15, 6: 285-305.

Thompson, N. A., Herrmann, A. M. and Hekkert, M. P. (2015). How sustainable entrepreneurs engage in institutional change: Insights from biomass torrefaction in the Netherlands. Journal of Cleaner Production, 106: 608-618. Available at: http://doi.org/ 10.1016/j.jclepro.2014.08.011.

Thorgren, S., Wincent, J. and Boter, H. (2012). Small firms in multipartner R\&D alliances: Gaining benefits by acquiescing. Journal of Engineering and Technology Management, 29, 4: 453-467.

van de Vrande, V., de Jong, J., Vanhaverbeke, W. and de Rochemont, M. (2009). Open innovation in SMEs: Trends, motives and management challenges. Technovation, 29, 6-7: 423-437. Available at: http://doi.org/10.1016/j.technovation.2008.10.001. 
van den Berg, W. and van der Slot, A. (2009). Clean Economy, Living Planet: Building the Dutch Clean Energy Technology Industry. Amsterdam.

van der Slot, A., van den Berg, W. and Berkhout, G. (2011). Clean Economy, Living Planet. Roland Berger. Washington, DC.

van Koophandel, K. (2005). BIK Boekje. Report, Chamber of Commerce. Amsterdam, NL.

Vergne, J. P. (2010). Toward a new measure of organizational legitimacy: Method, validation, and illustration. Organizational Research Methods, 14, 3: 484-502. Available at: http:// doi.org/10.1177/1094428109359811.

Walsh, V., Niosi, J. and Mustar, P. (1995). Small-firm formation in biotechnology: A comparison of France, Britain and Canada. Technovation, 15, 5: 303-327. Available at: http://doi.org/10.1016/0166-4972(95)96602-P.

Winch, G. M. and Courtney, R. (2007). The organization of innovation brokers: An international review. Technology Analysis \& Strategic Management, 19, 6: 747-763. Available at: http://doi.org/10.1080/09537320701711223.

Zeng, S. X., Xie, X. M. and Tam, C. M. (2010). Relationship between cooperation networks and innovation performance of SMEs. Technovation, 30, 3: 181-194.

Zimmerman, M. A. and Zeitz, G. J. (2002). Beyond survival: Achieving new venture growth by building legitimacy. Academy of Management Review, 27, 3: 414-431. Available at: http://doi.org/10.5465/AMR.2002.7389921.

Zucker, L. G. (1989). Combining institutional theory and population ecology: No legitimacy, no history. American Sociological Review, 54, 4: 542-545.

Zucker, L. G., Darby, M. R. and Armstrong, J. (1998). Geographically localized knowledge: Spillovers or markets? Economic Inquiry, 36, 1: 65-86.

Zucker, L. G., Darby, M. R. and Armstrong, J. S. (2002). Commercializing knowledge: University science, knowledge capture, and firm performance in biotechnology. Management Science, 48, 1: 138-153.

\section{Biography}

Neil A. Thompson is an Assistant Professor of Organization and Entrepreneurship Studies at the School of Economics and Business, Vrije Universiteit (VU) Amsterdam. His research interests include topics of creativity and imagination, emotional dimensions and lived experiences of entrepreneurship, social entrepreneurship, and institutional change.

Andrea M. Herrmann is an Assistant Professor of Innovation Studies at the Department of Innovation, Environmental and Energy Studies, Utrecht University. She studies institutional influences on incumbent firms, entrepreneurial ventures and workforces.

Marko P. Hekkert is a Professor of Innovation at the Department of Innovation, Environmental and Energy Sciences and Chairman of the Copernicus Institute of Sustainable Development, Utrecht University. His research interests include the dynamics of emerging technological fields that contribute to a more sustainable society. 